\title{
OSTEOARTHRITIS OF THE KNEE IN THE ELDERLY: IS KNEE REPLACEMENT ALWAYS JUSTIFIED?
}

Lychagin AV, Garkavi AV $\bowtie$, Meshcheryakov VA, Kaykov VS

Faculty of General Medicine, I. M. Sechenov First Moscow State Medical University, Moscow, Russia

Osteoarthritis is a condition that mostly affects the elderly population and tends to be localized to the knee joint. At old age, active treatment options are limited by co-morbidities and a higher risk for surgical complications. Therefore, the search for strategies that could become a temporary alternative to knee replacement is a pressing concern. The aim of this study was to analyze how justifiable is total knee replacement in elderly patients with knee osteoarthritis and to propose a less aggressive therapeutic alternative to this surgery. The study included 178 patients over 60 years of age with clinically established knee osteoarthritis who had been previously recommended knee replacement but chosen not to undergo it. The choice of a treatment strategy tested in the study was based on the original grading scale for the evaluation of the knee joint dislocation syndrome. The treatment consisted of therapeutic arthroscopy and intraarticular injections of hyaluronic acid and platelet-rich plasma (PRP). The data were processed in Statistica 12. Data analysis revealed that $39.3 \%$ of the participants did not have compelling indications for knee replacement. The proposed combination therapy with intraarticular PRP injections and arthroscopy allowed all the patients to delay knee replacement for at least a year; unaided by arthroscopy, intraarticular injections worked well for only $40 \%$.

Keywords: knee arthroplasty, total knee replacement, arthroscopy of the knee, intraarticular injection

Author contribution: Lychagin AV devised a KJDS scale, planned the study, performed arthroscopy and follow-up observation, processed and analyzed the data. Garkavi AV planned the study and proposed its design, performed arthroscopy, intraarticular injections and follow-up observation, processed and analyzed the data, and wrote the manuscript. Meshcheryakov VA performed arthroscopy, intraarticular injections and follow-up observation, surveyed the patients. Kaykov VS performed arthroscopy, intraarticular injections, and follow-up observation, surveyed the patients.

Compliance with ethical standards: this study was approved by the Ethics Committee of I. M. Sechenov First Moscow State Medical University (Protocol No. 17-18 dated 2018); the patients gave informed consent to participate.

$\triangle$ Correspondence should be addressed: Andrey V. Garkavi Trubetskaya 8, bld. 2, Moscow, 119991; Avgar22@yandex.ru

Received: 13.09.2018 Accepted: 25.03.2019 Published online: 06.04.2019

DOI: 10.24075/brsmu.2019.020

\section{ОСТЕОАРТРОЗ КОЛЕННОГО СУСТАВА У ПОЖИЛЫХ — ВСЕГДА ЛИ ОПРАВДАНО ЭНДОПРОТЕЗИРОВАНИЕ?}

А. В. Лычагин, А. В. Гаркави

Лечебный факультет, Первый московский государственный медицинский университет имени И. М. Сеченова (Сеченовский Университет), Москва, Россия

Остеоартроз - заболевание преимущественно пожилых людей, и по локализации первое место уверенно удерживает коленный сустав. Именно в пожилом и старческом возрасте возможность активного лечения пациентов с гонартрозом ограничена их полиморбидностью, а также повышенным операционным риском. Поэтому весьма актуален поиск методик лечения, способных хотя бы на время стать альтернативой эндопротезированию коленного сустава. Целью исследования было проанализировать оправданность операции эндопротезирования коленного сустава у пациентов пожилого и старческого возраста с гонартрозом и разработать комплексную систему лечения, сохраняющую сустав. В исследовании участвовали 178 пациентов старше 60 лет, которым ранее было предложено, но не выполнено эндопротезирование коленного сустава по поводу верифиицированного гонартроза. Для определения лечебной тактики использовали оригинальную балльную систему оценки дислокационного синдрома коленного сустава. Применяли сочетание санационной артроскопии с внутрисуставным введением гиалуроновой кислоты и обогащенной тромбоцитами аутоплазмы (PRP). Для анализа результатов определяли статистическую значимость отмеченных отличий по стандартному пакету программ «Statistica 12.0». Показано, что 39,3\% пациентов эндопротезирование было предложено без достаточных объективных оснований. Проведение комплексного лечения, сочетающего внутрисуставную PRP-терапию с предварительно проведенной санационной артроскопией, стало альтернативой эндопротезированию для всех пациентов как минимум на год, а внутрисуставная терапия без артроскопии - только для 40\%.

Ключевые слова: эндопротезирование коленного сустава, артроскопия, внутрисуставная инъекционная терапия

Информация о вкладе авторов: А. В. Лычагин - создание шкалы оценки степени ДСКС, планирование исследования, выполнение операций артроскопии, послеоперационное наблюдение, систематизация и анализ результатов; А. В. Гаркави - планирование и создание дизайна исследования, операции артроскопии, внутрисуставные инъекции, наблюдение пациентов в динамике, систематизация и анализ результатов, оформление статьи; В. А. Мещеряков - артроскопия, внутрисуставные инъекции, наблюдение и анкетирование пациентов; В. С. Кайков - артроскопия, внутрисуставные инъекции, наблюдение и анкетирование пациентов.

Соблюдение этических стандартов: исследование одобрено этическим комитетом ФГАОУ ВО Первый МГМУ им. И. М. Сеченова (протокол № 17-18, 2018 г.); все пациенты подписали добровольное информированное согласие на участие в проводимом исследовании.

$\bowtie$ Для корреспонденции: Андрей Владимирович Гаркави

ул. Трубецкая, д. 8, стр. 2, г. Москва, 119991; Avgar22@yandex.ru

Статья получена: 13.09.2018 Статья принята к печати: 25.03.2019 Опубликована онлайн: 06.04.2019

DOI: $10.24075 /$ vrgmu.2019.020

Osteoarthritis of the knee is one of the most common orthopedic conditions. Presenting with pain and the loss of joint function, it debilitates the patient leaving them unable to engage in the usual daily activities. Most typically, osteoarthritis affects the elderly, causing a dramatic impact on their social life, making them dependent on others and leading to depression [1-5].
On the one hand, conservative treatment of knee osteoarthritis in elderly patients with marked age-related changes in the joint merely seeks to achieve temporary relief. On the other hand, advances in arthroplasty techniques have made knee replacement safer, less traumatic and more available [6-12]. 
In recent years, arthroplasty in the elderly has been on the rise because the indications for this procedure have been expanded [13-15]. Sometimes, the severity of medically diagnosed knee osteoarthritis seems to leave no other option for an aging patient but a knee replacement; other, less aggressive treatments, such as arthroscopy, systemic medication therapy, intraarticular injections, or physical rehabilitation, are not even considered by the physician. But if we really think about it, doesn't it deprive patients of the chance to avoid a surgical intervention that, in spite of the advances in the medical science, still poses certain health risks $[16,17]$ ?

Unfortunately, there is no universal approach to establishing compelling indications for endoprosthetic knee replacement; therefore, this surgery may not always be a reasonable or adequate therapeutic option.

The aim of this study was to analyze how justifiable is total knee replacement (TKR) in elderly patients with knee osteoarthritis and to propose a less aggressive alternative to this surgery.

\section{METHODS}

We had 178 retired patients aged 60 to 82 years in our care who had been previously offered to undergo TKR but chosen not to for a variety of reasons (fear of surgery, a long waiting list, etc.). The patients agreed to try an alternative treatment strategy and then revisit the idea of surgery. The study included patients aged over 60 years with a previously established diagnosis of knee osteoarthritis and a recommendation to have knee replacement surgery, who gave written informed consent to try a different treatment strategy developed by the authors of this work. The treatment course and the follow-up observation period lasted for 1 year each. The following exclusion criteria were applied: severe comorbidities that significantly limited patients' ability to walk or were a direct contraindication for the offered rehabilitation; intraarticular fractures with persisting joint incongruence; failure to cooperate.

The grading scale proposed by Lychagin AV [18] was applied to determine the severity of the knee joint dislocation syndrome (KJDS) in the examined patients. The following parameters were evaluated: degeneration of the articular cartilage, paraarticular bone damage, joint instability, the narrowing of the joint space, and the total WOMAC score. Each parameter was scored on a scale of 0 to 4; the maximum total score was 20 points.

The total of $0-5$ points scored on this scale suggested that a patient could benefit from a conservative medication therapy; 6-12 points, a complex treatment including arthroscopy and intraarticular injections should be offered; 13-20 points, a patient should be advised to undergo TKR.

Of 178 patients with stage II/III knee osteoarthritis (according to Kellgren-Lawrence classification) who had been recommended to undergo TKR, only 108 (60.7\%) scored 13 points

Table 1. The evaluation of the severity of the knee joint dislocation syndrome (KJDS) expressed in points

\begin{tabular}{|c|c|c|}
\hline Changes to the anatomy or function & Severity of pathology & Score (points) \\
\hline \multirow{5}{*}{$\begin{array}{l}\text { Articular cartilage (classification by ICRS) evaluated } \\
\text { by MRI or arthroscopy }\end{array}$} & normal & 0 \\
\hline & Grade 1-2 & 1 \\
\hline & Grade 3 & 2 \\
\hline & Grade 4 (slight defect < $2.5 \mathrm{~cm}^{2}$ ) & 3 \\
\hline & Grade 4 (significant defect $>2.5 \mathrm{~cm}^{2}$ ) & 4 \\
\hline \multirow{5}{*}{ Paraarticular bone region } & - normal & 0 \\
\hline & - osteoporosis & 1 \\
\hline & - cysts & 2 \\
\hline & - mild bone deformity & 3 \\
\hline & - pronounced bone deformity & 4 \\
\hline \multirow{5}{*}{ Joint instability } & No instability detected & 0 \\
\hline & Compensated (grade 1) & 1 \\
\hline & Subcompensated (grade 2) & 2 \\
\hline & Uncompensated (grade 3) & 3 \\
\hline & Arthrogenic contractures & 4 \\
\hline \multirow{5}{*}{ Narrowing of the joint space (\%) } & $0-5$ & 0 \\
\hline & $6-30$ & 1 \\
\hline & $31-50$ & 2 \\
\hline & $51-75$ & 3 \\
\hline & $76-100$ & 4 \\
\hline \multirow{5}{*}{ WOMAC score (points) } & $\leq 30$ & 0 \\
\hline & $31-50$ & 1 \\
\hline & $51-70$ & 2 \\
\hline & $71-90$ & 3 \\
\hline & $>90$ & 4 \\
\hline
\end{tabular}


and above; this confirms that surgery is justifiable for such patients (Fig. 1).

The patients were distributed into 3 groups. Group 1 consisted of 54 patients who received intraarticular plateletrich plasma (PRP) injections; group 2 was constituted by 64 individuals who received intraarticular injections of hyaluronic acid. The patients from group 3 received systemic medication therapy (chondroprotective agents + non-steroidal antiinflammatories).

Knee arthroscopy was performed on 118 patients who had scored 6 or more points on the KJDS scale. Of them $32(59.3 \%)$ were from group 1, $44(68.8 \%)$ from group 2, and 42 (70.0\%) from group 3 (Fig. 2).

\section{RESULTS}

The patients were divided into several groups based on the severity of osteoarthritis. The severity of the condition was inferred from their total KJDS scores that reliably showed whether the patient needed knee replacement; unlike this scale, radiographic findings do not always correlate with patients' complaints of pain and decreasing lifestyle, so we did not use them as a criterium. Of 178 patients who had been recommended TKR, as many as 70 turned to have no compelling indication for surgery (Table 2).

This, however, does not mean that by the end of observation the patients were fully determined to never revisit the idea of a surgical intervention, but rather suggests that they were satisfied with the outcomes of an alternative treatment strategy

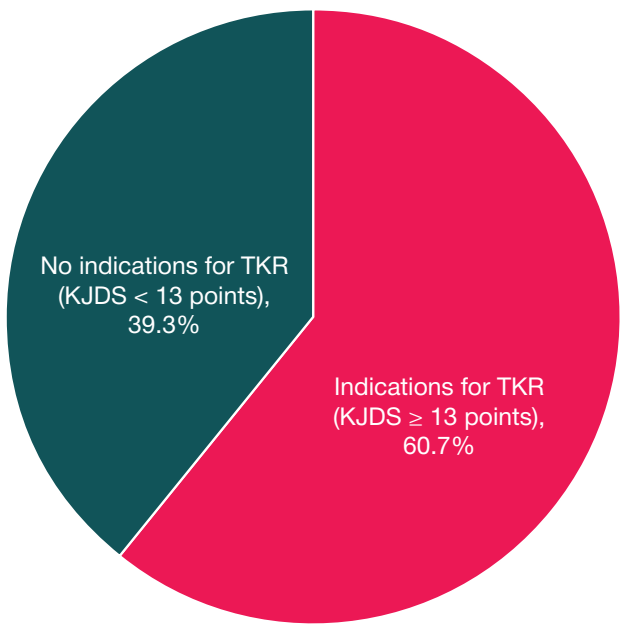

Fig. 1. Indications for knee replacement based on the KJDS score in patients who had been previously recommended to undergo TKR for the time being and did not intend to have TKR in the nearest future.

Of 70 patients who had been offered to undergo TKR without having a compelling indication for it (KJDS $<13$ points), only $15(21.4 \%)$ still thought that surgery would be beneficial for them, even after completing the treatment course. Those were mostly patients from group 3 (no intraarticular injections administered): 13 individuals out of 28 , or $46.4 \%$. All patients from group 1 (100\%) and 22 patients from group $2(91.7 \%)$ decided they no longer wanted knee replacement (Fig. 3).

Of 108 patients with severe articular damage and indications for TKR (KJDS $\geq 13$ points), 39 (36.1\%) still thought about having surgery after completing the treatment course. Therefore, it can be assumed that 69 (63.9\%) patients believed that their condition had significantly improved (Fig. 4).

The patients receiving intraarticular injection therapy benefited the most from the treatment course and saw it as a real alternative to surgery $(86.1 \%$ in group 1 and $77.5 \%$ in group 2). At the same time in group 3, 25 of 32 patients (78.1\%) still considered TKR as an option because they were not satisfied with the result, although $90.6 \%$ of those patients had received therapeutic arthroscopy.

\section{DISCUSSION}

The efficacy of intraarticular injections and therapeutic arthroscopy at the onset of treatment can be assessed separately or in combination with each other.

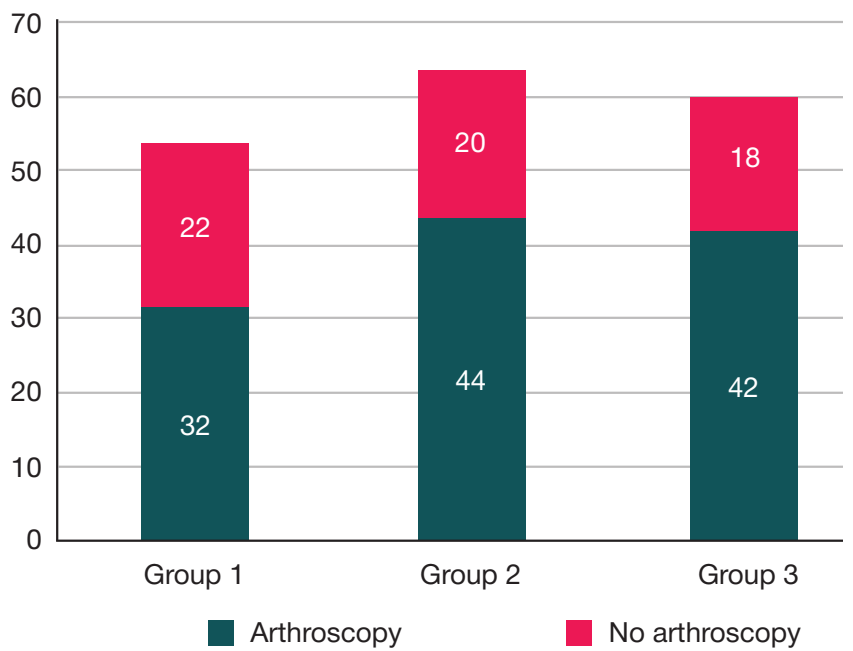

Fig. 2. The distribution of patients based on therapeutic arthroscopy

Table 2. Patients' attitude to TKR a year after completing the suggested treatment course

\begin{tabular}{|c|c|c|c|c|c|c|}
\hline & \multirow{2}{*}{\multicolumn{2}{|c|}{$\begin{array}{l}\text { Number of patients who agreed to try a } \\
\text { different treatment strategy instead of TKR }\end{array}$}} & \multicolumn{2}{|r|}{$\begin{array}{l}\text { Number of patients who received } \\
\text { therapeutic arthroscopy }\end{array}$} & \multicolumn{2}{|c|}{$\begin{array}{l}\text { Number of patients who did not receive } \\
\text { therapeutic arthroscopy }\end{array}$} \\
\hline & & & \multirow{2}{*}{$\begin{array}{c}\text { Total } \\
5 \\
\end{array}$} & \multirow{2}{*}{$\begin{array}{c}\text { Of them, number of patients willing } \\
\text { to reconsider TKR after completing } \\
\text { the treatment course }\end{array}$} & \multirow{2}{*}{$\begin{array}{c}\text { Total } \\
13 \\
\end{array}$} & \multirow{2}{*}{$\begin{array}{l}\text { Of them, number of patients willing } \\
\text { to reconsider TKR after completing } \\
\text { the treatment course }\end{array}$} \\
\hline Group 1 & No compelling indication for TKR & 18 & & & & \\
\hline$(n=54)$ & TKR justified & 36 & 27 & 0 & 9 & $5(55.6 \%)$ \\
\hline \multirow{2}{*}{$\begin{array}{l}\text { Group } 2 \\
(n=64)\end{array}$} & No compelling indication for TKR & 24 & 15 & 0 & 9 & $2(22.2 \%)$ \\
\hline & TKR justified & 40 & 29 & $2(6.9 \%)$ & 11 & $7(63.6 \%)$ \\
\hline \multirow{2}{*}{$\begin{array}{l}\text { Group } 3 \\
(n=60)\end{array}$} & No compelling indication for TKR & 28 & 13 & $4(30.8 \%)$ & 15 & $9(60.0 \%)$ \\
\hline & TKR justified & 32 & 29 & 22 (75.9\%) & 3 & $3(100 \%)$ \\
\hline \multirow{2}{*}{$\begin{array}{l}\text { Total } \\
(n=178)\end{array}$} & No compelling indication for TKR & 70 & 33 & $4(12.1 \%)$ & 37 & $11(29.7 \%)$ \\
\hline & TKR justified & 108 & 85 & 24 (28.2\%) & 23 & 15 (65.2\%) \\
\hline
\end{tabular}


If we look at the efficacy of intraarticular injections alone, we should note that of 118 patients from groups 1 and 2, who had previously considered a possibility of surgical intervention, 42 had no compelling indications for surgery. After completing a course of intraarticular PRP or hyaluronic acid injections, only 2 (4.8\%) patients still thought of undergoing TKN versus 13 (46.4\%) out of 28 patients in group 3 who had no injection therapy.

Seventy-six patients from groups 1 and 2 had serous indications for surgery and received intraarticular injections. Of them, only 14 (18.4\%) did not give up the idea of surgery after completing the treatment course.

In group 1, 32 of 54 patients received therapeutic arthroscopy. If we look at the efficacy of this procedure performed at the beginning of the treatment course, we will see that none of those 32 patients was still willing to undergo TKR a year after completing the treatment course. In group 2, 44 of 64 patients received arthroscopy, and only 2 (4.5\%) of them decided they were satisfied with the result. In group 3 , 42 of 60 patients received therapeutic arthroscopy, and TKR was still considered by 18 of them (42.9\%) a year later, whereas $14(77.8 \%)$ of 18 "arthroscopy-free" patients still thought they would benefit from TKR (Table 2).

Unsurprisingly, in patients who had no compelling indications for TKR, our treatment course tended to be a good alternative

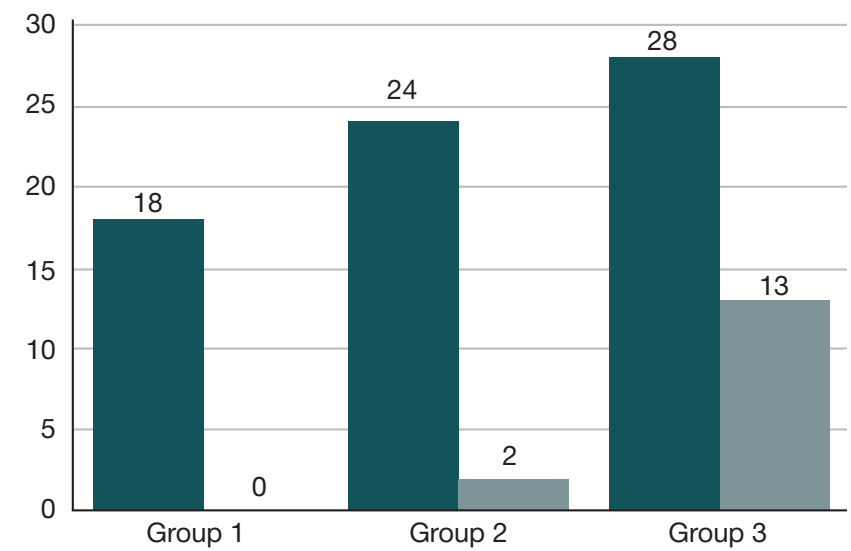

The total number of patients recommended to undergo TKR

The number of patients still considering TKR

Fig. 3. The attitude of patients who had no compelling indications for TKR to this surgical intervention after completing the suggested treatment course

After arthroscopy

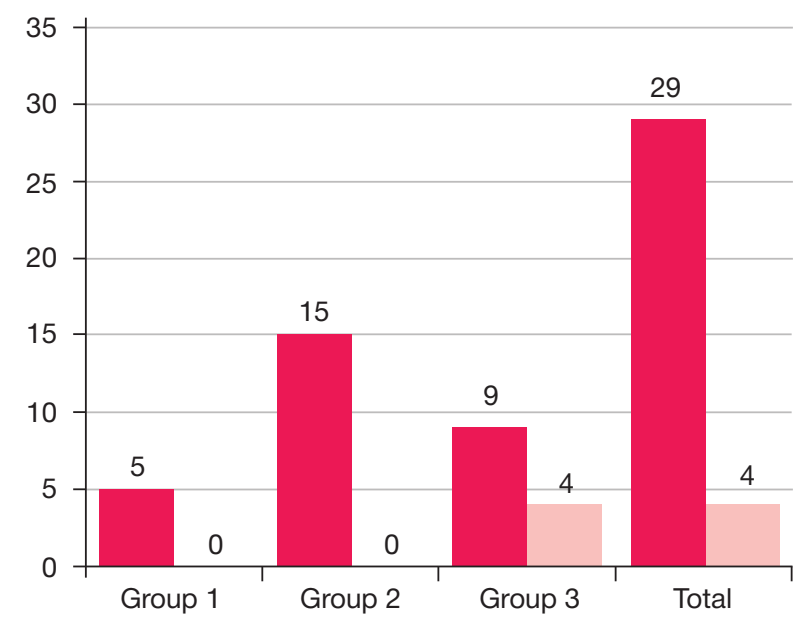

Decided against TKR to surgery. After arthroscopy, 29 (87.9\%) of 33 patients said they had benefited from it. The proportion of such patients in groups 1 and 2 was $100 \%$. Thirty-seven (77.1\%) of 48 patients who had not received arthroscopy were able to delay or avoid TKR; the proportion of such patients was 100\% in group 1, $81.8 \%$ in group 2 and $62.5 \%$ in group 3 (Fig. 5).

Of all the patients who had objective indications for TKR, $71.7 \%$ (61 of 85 individuals) decided against after the treatment course. The proportion of such patients was $100 \%$ in group 1 , $93.1 \%$ in group 2 and only $24.1 \%$ in group 3, which confirms the efficacy of intraarticular PRP injections included into the complex therapy of knee osteoarthritis. Arthroscopy was not performed in 23 patients who had objective indications for TKR. Of them, only 8 (34.8\%) benefited temporarily from the suggested therapy course, more specifically intraarticular injections: 4 (44.4\%) of 9 patients in group 1 and 4 (36.4\%) of 11 patients in group 2 (Fig. 6).

\section{CONCLUSIONS}

1) Endoprosthetic knee replacement is often overused in elderly patients with osteoarthritis who do not have compelling indications for this surgical procedure. The KJDS grading scale proposed by Lychagin AV shows that only $60.7 \%$ of

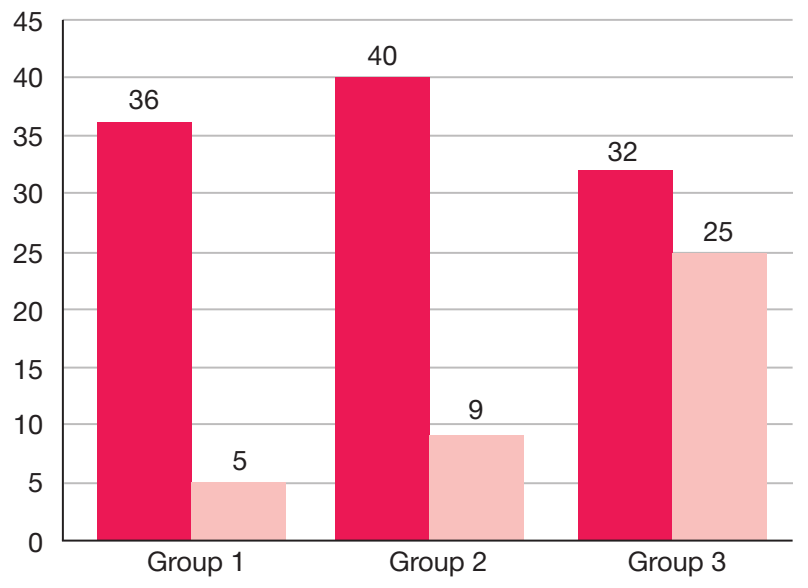

The total number of patients recommended to undergo TKR

The number of patients still considering TKR

Fig. 4. The attitude of patients who had compelling indications for TKR to this surgical intervention after completing the suggested treatment course

No arthroscopy

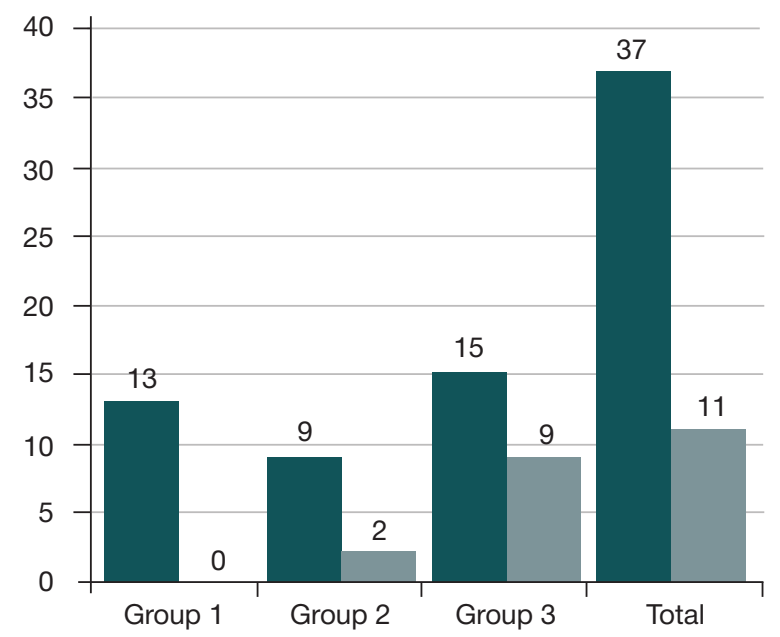

Decided against TKR Decided in favor of TKR

Fig. 5. The impact of arthroscopy on the attitude to TKR in patients with no compelling indication for TKR 
After arthroscopy

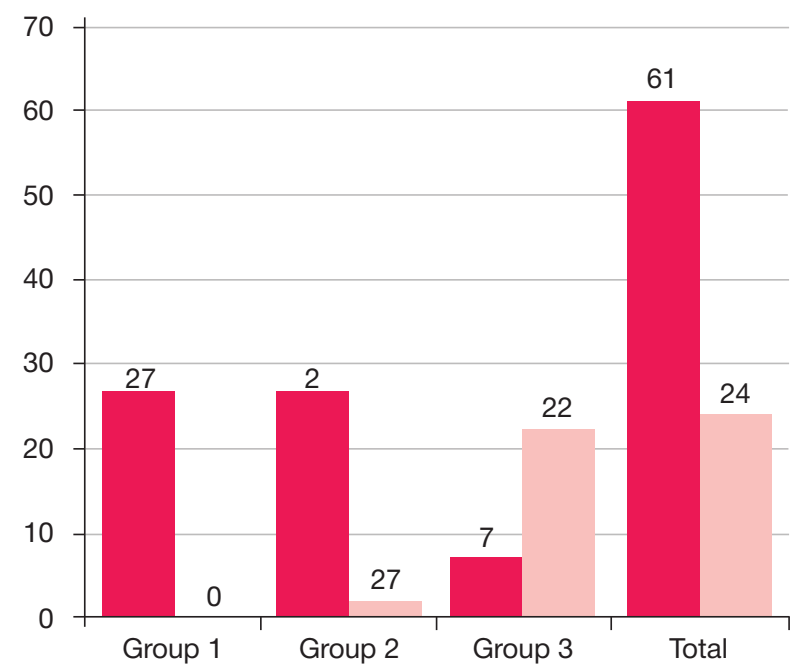

Decided against TKR Decided in favor of TKR
No arthroscopy

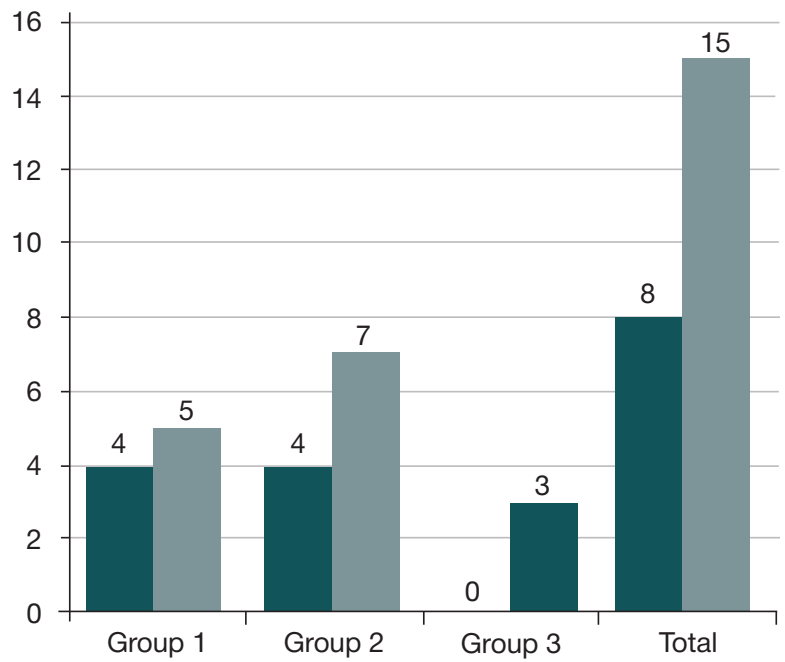

Decided against TKR Decided in favor of TKR

Fig. 6. The impact of arthroscopy on the attitude to TKR in patients with compelling indications for TKR

such patients have objective indications for surgery. 2) A combination therapy with arthroscopy and intraarticular PRP injections ensures durable improvement that can delay TKR for at least a year. 3) Unaided by arthroscopy, intraarticular injectins can be an alternative to knee replacement in $40.0 \%$ of patients with compelling indications for TKR.

\section{References}

1. Bragina SV, Matveev RP. Struktura stojkoj utraty trudosposobnosti u pacientov s gonartrozom. Genij ortopedii. 2011; (4): 96-100.

2. Savelova EE, Majko OYu. Kachestvo zhizni bol'nyh gonartrozom po ankete ER-50. Materialy II Vserossijskogo kongressa revmatologov Rossii. Yaroslavl', $2011 \mathrm{~g} ; 68$.

3. Hamroeva ZD. Ocenka klinicheskogo techeniya i osobennostej lecheniya osteoartroza u lic pozhilogo i starcheskogo vozrasta. [dissertacya]. Dushanbe, 2016.

4. Curko W, Egorov IV, Krasnoselskij MYA. Sustavnoj sindrom u pozhilyh: Patofi-ziologiya boli i kliniko-vozrastnye aspekty terapii. Consilium Medicum. 2009; 11 (2): 2-10.

5. Shukurova SM, Hamroeva ZD, SHodiev BR. Osteoartroz kak vazhnaya problema geriatrii. Vestnik Avicenny. 2015; (1): 137-143.

6. Vignon E, Valat JP, Rossignol M, et al. Osteoarthritis of the knee and hip and activity: a systematic international review and synthesis (OASIS). Joint Bone Spine. 2006; (73): 442-55.

7. Alekseeva LI, Cvetkova ES. Osteoartroz: iz proshlogo v budushchee. Nauchno-prakticheskaya revmatologiya. 2009; (2): 31-39.

8. Batpenov ND, Bajmagambetov ShA i dr. Artroskopiya kolennogo sustava pri osteoart-roze kolennogo sustava. Materialy VII Kongressa Rossijskogo artroskopicheskogo obshchestva. M., 2007; 49.

9. Dubrov VEh, Yarema IV, Rebrov VN. Kompleksnoe lechenie degenerativno-vospalitel'nyh porazhenij kolennogo sustava u pozhilyh bol'nyh. Travmatologiya i ortopediya Rossii. 2005; (35): 49.
10. Zabolotnyh II, Zabolotnyh VA. Bolezni sustavov $\vee$ pozhilom vozraste. SPb.: "Petropolis", 2000; 144.

11. Karateev DE. Farmakoterapiya osteoartroza: ehffektivnost' i bezopasnost'. Poliklinika. 2010; (5): 74-9.

12. Sinusas K. Osteoarthritis: diagnosis and treatment. Am Fam Physician. 2012; 85 (1): 49-56.

13. Kavalerskij GM, Lychagin AV, Smetanin SM i dr. Istoricheskoe razvitie koncepcii ehndoprotezirovaniya kolennogo sustava. Kafedra travmatologii i ortopedii. 2016; (3): 16-20.

14. Tarbushkin AA. Ocenka strukturno-funkcional'nyh narushenij kolennogo sustava dlya opredeleniya pokazaniya $k$ ehndoprotezirovaniyu pri gonartrozah [dissertaciya]. M., 2013.

15. Tihilov RM, Shubnyakov II, Kovalenko AN i dr. Dannye registra ehndoprotezirovaniya tazobedrennogo sustava RNIITO im. R. R. Vredena za 2007-2012 gody. Travmatologiya i ortopediya Rossii. 2013; (3): 167-90.

16. Sereda AP, Gricyuk AA, Zelenyak KB, Serebryakov AB. Faktory riska infekcionnyh oslozhnenij posle ehndoprotezirovaniya kolennogo sustava. Infekcii v hirurgii. 2010; 8 (4): 67-76.

17. Gioe TJ, Killeen KK, Grimm K, et al. Why are total knee replacements revised? Analysis of early revision in a community knee implant registry. Clin Orthop Relat Res. 2004; (428): 100-6.

18. Lychagin AV. Hirurgicheskoe lechenie strukturno-funkcional'nyh narushenij pri gonartroze [dissertaciya]. M., 2017.

\section{Литература}

1. Брагина С. В., Матвеев Р. П. Структура стойкой утрать трудоспособности у пациентов с гонартрозом. Гений ортопедии. 2011; (4): 96-100.

2. Савелова Е. Е., Майко О. Ю. Качество жизни больных гонартрозом по анкете ЕР-50. В сборнике: Материалы ॥ Всероссийского конгресса ревматологов России; 26-29 апреля; Ярославль, 2011 г.; 68.
3. Хамроева 3. Д. Оценка клинического течения и особенностей лечения остеоартроза у лиц пожилого и старческого возраста [диссертация]. Душанбе, 2016.

4. Цурко В. В., Егоров И. В., Красносельский М. Я. Суставной синдром у пожилых: Патофизиология боли и клиниковозрастные аспекты терапии. Consilium Medicum. 2009; 11 (2): 2-10. 5. Шукурова С. М., Хамроева З. Д., Шодиев Б. Р., Каримова Г. Н. 
Остеоартроз как важная проблема гериатрии. Вестник Авиценны. 2015; (1): 137-43.

6. Vignon $\mathrm{E}$, Valat JP, Rossignol $\mathrm{M}$, et al. Osteoarthritis of the knee and hip and activity: a systematic international review and synthesis (OASIS). Joint Bone Spine. 2006; (73): 442-55.

7. Алексеева Л. И., Цветкова Е. С. Остеоартроз: из прошлого в будущее. Научно-практическая ревматология. 2009; (2): 31-39.

8. Батпенов Н. Д., Баймагамбетов Ш. А. и др. Артроскопия коленного сустава при остеоартрозе коленного сустава. В сборнике: Материалы VII Конгресса Российского артроскопического общества; 17-19 декабря 2007 г;; Москва. М.: 49

9. Дубров В. Э., Ярема И. В., Ребров В. Н. Комплексное лечение дегенеративно-воспалительных поражений коленного сустава у пожилых больных. Травматология и ортопедия России. 2005; (35): 49.

10. Заболотных И. И., Заболотных В. А. Болезни суставов в пожилом возрасте. СПб.: Петрополис, 2000; 144 с.

11. К Каратеев Д. Е. Фармакотерапия остеоартроза: эффективность и безопасность. Поликлиника. 2010; (5): 74-9.

12. Sinusas K. Osteoarthritis: diagnosis and treatment. Am Fam Physician. 2012; 85 (1): 49-56.
13. Кавалерский Г. М., Лычагин А. В., Сметанин С. М. и др. Историческое развитие концепции эндопротезирования коленного сустава. Кафедра травматологии и ортопедии. 2016; (3): 16-20.

14. Тарбушкин А. А. Оценка структурно-функциональных нарушений коленного сустава для определения показания к эндопротезированию при гонартрозах [диссертация] М., 2013.

15. Тихилов Р. М., Шубняков И. И., Коваленко А. Н. и др. Данные регистра эндопротезирования тазобедренного сустава РНИИТО им. Р. Р. Вредена за 2007-2012 годы. Травматология и ортопедия России. 2013; (3): 167-90.

16. Середа А. П., Грицюк А. А., Зеленяк К. Б., Серебряков А. Б. Факторы риска инфекционных осложнений после эндопротезирования коленного сустава. Инсекции в хирургии. 2010; 8 (4): 67-76.

17. Gioe TJ, Killeen KK, Grimm K, et al. Why are total knee replacements revised? Analysis of early revision in a community knee implant registry. Clin Orthop Relat Res. 2004; (428): 100-6.

18. Лычагин А. В. Хирургическое лечение структурно-срункциональных нарушений при гонартрозе [диссертация]. М., 2017. 